\title{
Post harvest physicochemical properties of soursop (Annona muricata L.) fruits of Coast region, Tanzania
}

\author{
Othman Chande Othman", ", Christina Fabian², Esther Lugwisha ${ }^{1}$ \\ ${ }^{1}$ University of Dar es Salaam, Chemistry Department, P. O. Box 35061, Dar es Salaam, Tanzania \\ ${ }^{2}$ Mkwawa University College of Education, Chemistry Department, P.O. Box Private Bag, Iringa, Tanzania
}

Email address:

o_chande@yahoo.co.uk (Othman O. C.), tina84f@yahoo.com (Fabian C.), elugwisha@gmail.com (Lugwisha E.)

\section{To cite this article:}

Othman Chande Othman, Christina Fabian, Esther Lugwisha. Post Harvest Physicochemical Properties of Soursop (Annona Muricata L.) Fruits of Coast Region, Tanzania. Journal of Food and Nutrition Sciences. Vol. 2, No. 5, 2014, pp. 220-226.

doi: $10.11648 /$ j.jfns.20140205.13

\begin{abstract}
The physicochemical composition of harvested soursop (Annona muricata L.) fruits from Coast region, Tanzania, during open-air storage was determined. The ash, titratable acidity, crude fat, crude fiber, moisture and sugars content were determined by proximate analysis. Ascorbic acid contents were determined using the 2,6-dichlorophenol-indophenol dye method while macro-nutrients and heavy metals were determined by Flame Atomic Absorption Spectrophotometry (FAAS). The fruits were harvested at the mature ripe stage and kept in open air storage over several days. The determinations were done immediately after fruit arrival at the laboratory and thereafter at intervals of two days from the day of harvest. The results showed that soursop fruits had high moisture content $(73.1 \%-82.1 \%)$, low titratable acidity $(0.10-1.25 \% \mathrm{ca})$, low crude fat $(0.42 \mathrm{mg} / 100 \mathrm{~g}$-fw $)$, moderate ash content $(0.87 \mathrm{mg} / 100 \mathrm{~g}$-fw $)$ and crude fibre content $(6.09 \mathrm{mg} / 100 \mathrm{~g}$-fw), high ascorbic acid content $(34.0-19.7 \mathrm{mg} / 100 \mathrm{~g}$-fw), high total sugars content $(34.3 \%$ $45.3 \%)$, reducing sugar content $(18.9 \%-39.2 \%)$ and sucrose content $(15.5 \%-30.0 \%)$. Of the macroelements $\mathrm{Na}, \mathrm{Ca}$ and $\mathrm{K}$, the average content were 895.6, 870.3 and $367.5 \mathrm{mg} / 100 \mathrm{~g}$-fw respectively. Heavy metals ( $\mathrm{Fe}, \mathrm{Zn}, \mathrm{Cu}, \mathrm{Pb}$ and $\mathrm{Cd}$ ) content was very low in the soursop fruits, ranging between $<0.0015 \mathrm{mg} / 100 \mathrm{~g}$-fw for $\mathrm{Cd}$ and $0.82 \mathrm{mg} / 100 \mathrm{~g}$-fw for Fe. During storage, the moisture content, titratable acidity level and sugars content in the fruit were all increasing whereas the ascorbic acid content was decreasing. There were no significant changes during storage for levels of crude fat, fiber, ash, mineral elements and heavy metals. The findings from this study suggest that this fruit from coast region of Tanzania can contribute nutritionally to the health of the consumer.
\end{abstract}

Keywords: Soursop, Annona Muricata, Physicochemical, Proximate Analysis, Storage, Macronutrients, AAS, Post-Harvest, Tanzania

\section{Introduction}

Information on the nutrient composition of locally available foods especially fruits is of immense importance because of the need to supply foods according to their nutritive values to the people. Dietary supplements are now made using different fruits, vegetables and also herbs in order to provide natural curative as well as preventive methods for combating diseases and poor health. For Tanzania, as it is for other developing countries, there exists very limited information on the nutritive value of its many natural foods especially it's wild and underutilized fruits so that these may be utilized for such purposes. Soursop (Annona muricata L.) fruits are important fruits as they are not only a good source of vitamins, dietary fiber and minerals and provide flavor, aroma and texture to the pleasures of eating food but also are claimed have anticancer and antioxidant capabilities [1]. Studies [2, 3] suggest that compounds from soursop tested on breast cancer cells in culture were more effective than chemotherapy in destroying these cells. The soursop fruits are normally eaten fresh or as fresh soursop juice. There is growing interest in this fruit because it is considered to be a functional product of great benefit to the human diet as it contains several groups of substances that have anti-cancer and antioxidant properties that are useful in disease risk reduction. The soursop fruit and fruit juice are taken as medicine for worms and parasites, to 
cool fevers, to increase mother's milk after childbirth, and as an astringent for diarrhea and dysentery [4].

Because of the importance of fruits as valuable food resources many studies are being undertaken to establish the quality, physicochemical characteristics and storage ripening changes of the properties of fruits. Several research studies have been undertaken on the physicochemical composition of Tanzanian fruits and a few reports include those on mangoes [5], pineapples [6], papaya [7] and oranges [8]. So far little attention has been paid to less common fruits such as sugarapple, baobab, pomegranate and soursop. Heavy metal pollution of foods has provoked considerable research in the analysis of food and food products [9]. Some metals like cadmium, lead and mercury are major contaminants of food supply and may be considered the most dangerous elements to our environment while others like iron, zinc and copper are essential for biochemical reactions in the body [10]. Post harvest studies on fruits provide information that shows variation of fruit properties and the best beneficial time for consumption of the fresh fruit.

This study therefore reports on the post-harvest proximate composition (moisture, acidity, sugars, ash, crude fibers and crude fat content), ascorbic acid content, mineral elements and heavy metals content of soursop fruits from the Coast Region, Tanzania.

\section{Materials and Methods}

\subsection{Reagents}

The following analytical grade reagents were used in this study: hydrochloric acid (assay $37 \mathrm{w} / \mathrm{v}$, specific gravity 1.2), sulphuric acid (assay 95-98 w/v, specific gravity 1.840) and standard ascorbic acid (assay 99.7\%) as supplied by Aldrich Chemical Company Ltd, England. Copper sulphate (99\%) was obtained from Lab Tech chemicals Ltd and sodium hydroxide pellets (assay 97\%) were obtained from Techno Pharmchem India. 2,6-dichlorophenol-indophenol A.C.S. reagent and phenolphthalein indicator used were supplied by LOBAL Chemie Company. Potassium and sodium tartrate (assay 99\%) and citric acid (monohydrate) assay 99.8\% were supplied by Riedel-de Haen AG and ethanol (assay 95\% pure) was supplied by CARLO ERBA reagents of Italy. Acetic acid (glacial assay 99.5\%), nitric acid, perchloric acid, metaphosphoric acid (assay 88\% w/w) and methylene blue indicator as obtained from B.D.H Ltd, England, Lead acetate (assay < 99\%), potassium oxalate (assay 99.5\%) and phenolphthalein indicator ( $\mathrm{pH}$ range 8.3-10) were obtained from May \& Baker Ltd. Dagenham, England. Petroleum-ether (bp 60-80 ${ }^{\circ} \mathrm{C}$ ) was obtained from the Central Drug House Ltd. of India. Deionized distilled water was used for all needed dilutions.

\subsection{Instruments and Equipment}

An electronic balance Mettler Toledo model B 303-S, a Genlab oven supplied by Wideness Cheshire Ltd. having a temperature range of 0 to $250{ }^{\circ} \mathrm{C}$ and a muffle furnace, Gallenkamp Rapid Model, from Gallenkamp Ltd, having a heating temperature range up to $1000{ }^{\circ} \mathrm{C}$ were used. The Gallenkamp Centrifuge model 200 with frequency of $50 \mathrm{~Hz}$ from Gallenkamp Ltd, Osterizer blendor model 867-66A, an IKAMAG-RET type hot plate, a HANNA waterproof $\mathrm{pH}$-meter, a heating mantle of one litre, a soxhlet apparatus and the Flame Atomic Absorption Spectrophotometer, model iCE $3000 \mathrm{v} 1.3$ instrument were also used.

\subsection{Fruit Sample Collection}

Samples of soursop fruits were collected from farms in Mkuranga, Coast Region. Fully matured fruits that had no signs of wound or damage were picked directly from trees and were transported to the Chemistry Department laboratory, University of Dar es Salaam, for open-air, room temperature storage experiments and for further preparations and analysis.

\subsection{Analysis}

The following determinations were done in triplicate immediately after arrival of the fresh fruits at the laboratory and thereafter at intervals of two days from the day of harvest to the $8^{\text {th }}$ day. Moisture content, ash, crude fat, total sugars, ascorbic acid, other sugars and crude fibre were determined using standard methods (925.90, 923.03, 920.39, 977.20, 967.21, 932.12 and 935.53 respectively) of AOAC [11]. Titratable acidity was conducted following the method described by Rangana [12].

\subsection{Mineral Elements and Heavy Metals}

\subsubsection{Sample Preparation}

$1.0 \mathrm{~g}$ of a well dried and powdered fruit sample was placed in a digestion bottle followed by addition of $8 \mathrm{~mL}$ conc. nitric acid and $2 \mathrm{~mL}$ perchloric acid. The solution was then heated for about 4 hours with slow addition of drops of perchloric acid until a clear solution was obtained. The solution was then transferred to a $50 \mathrm{~mL}$ volumetric flask and made up to the mark by distilled water. Appropriate dilutions were done for elements present at high concentrations.

\subsubsection{Atomic Absorption Spectrophotometry (AAS)}

All determinations of metals were performed with the iCE 3000 v1.3 AAS instrument. Hollow cathode lamps of the different metals were used as radiation sources for the instrument. The instruction manual of the instrument was used as guide for all measurements. Calibration standards were first aspirated into the AAS to calibrate the instrument and check its linearity response. After all necessary set up, standardization and calibration procedures had been completed then the above treated fruit juice sample solutions were aspirated into the AAS instrument for precise measurement of metal concentration. All determinations, in triplicate, were performed at the laboratory of the Chemistry Department, University of Dar es Salaam. 


\section{Results and Discussion}

\subsection{Initial Proximate Composition}

The proximate composition (moisture, acidity, reducing sugars, total sugars, sucrose) and ascorbic acid content of soursop (Annona muricata L.) fruits immediately after collection from trees are presented in Table 1. All results are average results of triplicate determinations.

The average moisture content of the fruit was high at $73.1 \%$ but lower than the level of $82.8 \%$ reported by [13] and $81 \%$ reported by [14] for soursop fruits from Nigeria. The total sugars content of $34.3 \%$ makes the fruit sweet when fresh as compared to fruits from Brazil with a content of $14.6 \%$ [15]. The average reducing sugar content was $18.9 \%$ while the sucrose content was $15.5 \%$ which was much higher than the value of $1.02 \%$ reported by [16]. The titratable acidity value of $0.19 \%$ was lower than that reported by [13] and by Onimawo [14]. The ascorbic acid level of $34 \mathrm{mg} / 100 \mathrm{~g}$-fw was similar to the value of $34.7 \%$ reported by [17] for soursop from south eastern Nigeria and $37.25 \%$ reported for soursop of Brazil [15].

Table 1. Initial proximate composition (moisture, acidity, total sugars, reducing sugars, sucrose content) and ascorbic acid content of fresh soursop fruits from Coast Region, Tanzania

\begin{tabular}{ll}
\hline \multicolumn{2}{l}{ Fresh fruit average proximate composition $(\mathbf{n}=\mathbf{3})$} \\
\hline Parameter & Value \\
\hline Moisture (\%) & $73.1 \pm 3.1$ \\
Titratable acidity (\%) & $0.19 \pm 0.02$ \\
Total sugars (\%) & $34.3 \pm 1.5$ \\
Reducing sugars (\%) & $18.9 \pm 3.2$ \\
Sucrose (\%) & $15.5 \pm 0.8$ \\
Ascorbic acid (mg/100 g-fw) & $34.0 \pm 1.2$ \\
\hline
\end{tabular}

\subsection{Changes in Proximate Composition}

Open air storage results of proximate composition (moisture, titratable acidity, total sugars, reducing sugars, sucrose) and ascorbic acid level of soursop (Annona muricata L.) fruits from Coast Region, Tanzania are presented in Table 2 and Table 3.

\subsubsection{Moisture Content of the Fruit}

During storage ripening of the soursop fruits an increase in moisture content from $73.1 \%$ when harvested to $82.1 \%$ by the $6^{\text {th }}$ day of storage was observed but decreased to $80.5 \%$ on the $8^{\text {th }}$ day (Table 2). The above results are similar to values reported by [16] and Onimawo [14]. Such an increase in moisture level with open air storage has also been reported for Tanzanian pineapple fruits [6]. Increase in moisture content is beneficial as it makes the fresh fruit juicier and more palatable to the consumer. The decrease on the $8^{\text {th }}$ day may be due to drying up process of the fruit suggesting that soursop should only be stored for 6 days to get maximum juicy effect.

\subsubsection{Titratable Acidity}

Acidity in fruits plays an important role in taste, color, and microbial stability of the fruit juice and determines maturity.
Increase in titratable acidity from $0.19 \%$ to $1.25 \%$ was observed during the eight days of storage of the soursop fruits (Table 2). This behavior has also been reported for soursop fruits by [18] and for pineapple fruits by [6]. Normally high acidity makes fruits unacceptable to consumers even if they meet minimum sugar standards. However, the values of titratable acidity obtained make these fruits acceptable to consumers.

Table 2. Moisture, titratable acidity and total sugars content of soursop (Annona muricata L.) fruits during ambient storage

\begin{tabular}{llll}
\hline Storage days & $\begin{array}{l}\text { Moisture } \\
(\%)\end{array}$ & $\begin{array}{l}\text { Titratable acidity } \\
(\%)\end{array}$ & $\begin{array}{l}\text { Total sugars } \\
(\%)\end{array}$ \\
\hline 0 & $73.1 \pm 3.1$ & $0.19 \pm 0.02$ & $34.3 \pm 1.5$ \\
2 & $77.9 \pm 2.1$ & $0.29 \pm 0.05$ & $38.0 \pm 2.5$ \\
4 & $80.1 \pm 4.2$ & $0.60 \pm 0.04$ & $41.6 \pm 2.6$ \\
6 & $82.1 \pm 1.1$ & $1.11 \pm 0.02$ & $44.1 \pm 1.5$ \\
8 & $80.5 \pm 2.2$ & $1.25 \pm 0.06$ & $45.3 \pm 3.6$ \\
\hline
\end{tabular}

\subsubsection{Total Sugars}

During storage of a soursop fruits, there was an increase in total sugars and reducing sugars and sucrose content in the fruits. Soursop had an initial total sugar content of $34.3 \%$ at harvest and $45.3 \%$ by the $8^{\text {th }}$ day of storage (Table 2 ). These values are high when compared to the values of $7.6 \%, 14.6 \%$ and $10.1 \%$ reported by [13], [16] and [19] respectively. When sugars are consumed in large amounts they can easily lead to weight gain and other sugar-related health problems. Since soursop fruits have high amounts of vitamins, minerals, antioxidants and acetogenins they can still be consumed beneficially even though they have high amount of sugars.

\subsubsection{Reducing Sugar and Sucrose}

The reducing sugar content of soursop fruits increased from $18.9 \%$ at harvest to $39.2 \%$ by the $8^{\text {th }}$ day of storage and the sucrose content also increased from $15.5 \%$ at harvest to $30.0 \%$ on the $8^{\text {th }}$ day of open air storage (Table 3 ). These values are higher than the values of $9.91 \%$ for reducing sugars and $0.21 \%$ sucrose reported by [19]. The increase in sucrose might be due to enzymatic break down of polysaccharides into sugars [20]. This increase in sucrose is very important as it improves the sweetness of the fruit, a very important factor for the fruit consumers.

\subsubsection{Ascorbic Acid}

The average ascorbic acid content of the soursop fruits during storage ripening decreased from $34.0 \mathrm{mg} / 100 \mathrm{~g}$-fw at harvest to $19.7 \mathrm{mg} / 100 \mathrm{~g}$-fw by the $8^{\text {th }}$ day (Table 3 ). Soursop from the southern part of Nigeria showed an average ascorbic acid content of $70 \mathrm{mg} / 100 \mathrm{~g}$ [21]. Other reports show ascorbic acid content of soursop at 29.6 $\mathrm{mg} / 100 \mathrm{~g}$ [13], $22.6 \mathrm{mg} / 100 \mathrm{~g}$ [16] and $62.5 \mathrm{mg} / 100 \mathrm{~g}$ for soursop pulp from Ghana [22]. The high values of ascorbic acid in soursop signify the potential use of the fruit as a good antioxidant. High ascorbic acid levels of $51.8 \mathrm{mg} / 100 \mathrm{~g}-\mathrm{fw}$ have also been reported for papaya fruits of Hawaii [23]. The recommended daily intake (RDI) [24] of ascorbic acid is about $30 \mathrm{mg} /$ day for adults and $17 \mathrm{mg}$ /day for children. 
Therefore, these fruits could be considered as good sources of ascorbic acid for purposes of human nutrition.

Table 3. Reducing sugars, sucrose and ascorbic acid content of soursop (Annona muricata L.) fruits during ambient storage

\begin{tabular}{llll}
\hline $\begin{array}{l}\text { Storage } \\
\text { days }\end{array}$ & $\begin{array}{l}\text { Reducing } \\
\text { sugars }(\%)\end{array}$ & Sucrose $(\%)$ & $\begin{array}{l}\text { Ascorbic acid } \\
(\mathbf{m g} / \mathbf{1 0 0} \text { g-fw) }\end{array}$ \\
\hline 0 & $18.9 \pm 3.5$ & $15.5 \pm 0.8$ & $34.0 \pm 1.4$ \\
2 & $23.2 \pm 2.4$ & $18.2 \pm 0.4$ & $29.1 \pm 2.1$ \\
4 & $30.9 \pm 4.4$ & $19.4 \pm 2.6$ & $26.5 \pm 2.6$ \\
6 & $35.4 \pm 3.2$ & $21.4 \pm 1.9$ & $23.1 \pm 3.1$ \\
8 & $39.2 \pm 1.6$ & $30.0 \pm 1.4$ & $19.7 \pm 1.9$ \\
\hline
\end{tabular}

A comparative look at the data from reports of studies on physicochemical parameters of soursop by other researchers is presented in Table 4. The results show a wide variation of the values for the different parameters as the fruits are grown in different soils, climates and geographical locations. The percent moisture levels are similar in soursop fruits from different environments. The percent acidity varies from 0.19 (Tanzania) [this study] to 3.43 (Nigeria) [23] and the percent total sugars content varies from 7.5 (Ghana) [22] to 45.2 (Tanzania) [this study]. The reducing sugars content varies from $7.8 \%$ (Hawaii) [23] to $39.2 \%$ (Tanzania) [this study] whereas the sucrose varies from $0.21 \%$ (Brazil) [19] to $30.0 \%$ (Tanzania) [this study]. The ascorbic acid content varies from $19.7 \mathrm{mg} / 100 \mathrm{~g}$ (Tanzania) [this study] to 65.2 $\mathrm{mg} / 100 \mathrm{~g}-\mathrm{fw}$ (Ghana) [22].

Table 4. Comparison of globally reported proximate composition and ascorbic acid content of soursop (Annona muricata L.) fruits

\begin{tabular}{lll}
\hline Parameter & This study & Soursop literature \\
\hline $\begin{array}{l}\text { Moisture (\%) } \\
\text { Titratable acidity }\end{array}$ & 73.1 & $82.8[13], 81.0[14], 80.6[25]$, \\
$(\%)$ & 0.19 & $1.02[13], 3.43[14], 0.19[15]$ \\
$\begin{array}{l}\text { Total sugars (\%) } \\
\text { Reducing sugars }\end{array}$ & 34.3 & $7.59[13], 15.6[25], 20[28], 15[30]$ \\
$\begin{array}{l}\text { (\%) } \\
\text { Sucrose (\%) }\end{array}$ & 18.9 & $9.91[19], 7.8[23], 11[30]$ \\
$\begin{array}{l}\text { Ascorbic acid } \\
\text { (mg/100 g) }\end{array}$ & 34.0 & $0.21[19], 1.02[34]$ \\
\hline
\end{tabular}

\subsection{Ash, Crude Fat and Crude Fibre}

The results on determinations of ash, crude fat and crude fibre content are presented in Table 5.

\subsubsection{Ash}

Ash is the inorganic residue remaining after heating to remove all the water and organic matter that provides a measure of the total amount of minerals in a food. The main purpose of ash determination is to assess the quality of the food materials. High total ash content for a food material signifies the presence of adulterants [8]. The soursop fruits from Coast Region, Dar es Salaam, had an average ash content of $0.87 \pm 0.04 \mathrm{mg} / 100 \mathrm{~g}$-fw (Table 5). This value is higher than that reported by [30] and [32], compares well to the value of $0.73 \mathrm{mg} / 100 \mathrm{~g}$-fw reported by Moos [25] but is lower than the value of the ash content reported for soursop from Ghana [22]. The results in this study suggest that the fruits have high deposits of mineral elements.

Table 5. Ash, crude fat and crude fibre content of soursop (Annona muricata L.) fruits of Coast region, Tanzania

\begin{tabular}{lll}
\hline & This study & Soursop literature \\
\hline Parameter & $(\mathrm{mg} / 100 \mathrm{~g}-\mathrm{fw})$ & $(\mathrm{mg} / 100 \mathrm{~g}-\mathrm{fw})$ \\
Ash & $0.87 \pm 0.04$ & $2.44[22], 0.73[25], 0.58[30], 0.60[32]$ \\
Crude fat & $0.42 \pm 0.02$ & $2.60[22], 0.31[25], 0.97[32], 0.30[34]$ \\
Crude fibre & $6.09 \pm 0.61$ & $11.50[22], 1.63[25], 3.2[30], 3.3[34]$ \\
\hline
\end{tabular}

fw - fresh weight

\subsubsection{Crude Fat}

Crude fat represents the true fat and other materials such as phospholipids, sterols, essential oils and fat soluble pigments in the fruit. Generally fruits have low levels of fat content and this suggests that they are not good sources of energy. The average fat content in soursop fruits obtained in this study was $0.42 \pm 0.02 \mathrm{~g} / 100 \mathrm{~g}$-fw (Table 5). This value is higher than the value of $0.31 \mathrm{~g} / 100 \mathrm{~g}$-fw for soursop fruits as reported by Moos [25] and $0.22 \mathrm{~g} / 100 \mathrm{~g}$-fw for Tanzanian mangoes [5]. The low level of fat in the fruits means that these fruits are not good source of energy [22] and are recommended for loss or maintaining of weight, supply of nutrients and lowering of blood pressure [26, 27].

\subsubsection{Crude Fiber}

In Tanzania's soursop fruits the crude fibers observed in this study was $6.09 \pm 0.61 \mathrm{mg} / 100 \mathrm{~g}$-fw (Table 5 ). This value is higher than the values of $1.63 \mathrm{mg} / 100 \mathrm{~g}$-fw for soursop fruit reported by Moos [25] and lower than $11.5 \mathrm{mg} / 100 \mathrm{~g}$ reported for soursop from Ghana [22]. Fiber is essential to the human body as it helps to maintain the health of the gastrointestinal tract and in weight regulation [29] but if consumed in excess it may bind trace elements, leading to deficiency of iron and zinc in the body. The observed level of crude fibre in Tanzanian soursops is moderate and thus good for body maintenance.

\subsection{Mineral Elements and Heavy Metals}

The contents of the selected mineral elements (macroelements)-Ca, $\mathrm{Na}$, and $\mathrm{K}$ and heavy metals $-\mathrm{Fe}, \mathrm{Zn}$, $\mathrm{Cu}, \mathrm{Pb}$ and $\mathrm{Cd}$ in the soursop fruits from Coast region are summarized in Table 6.

Table 6. Macronutrients and heavy metal content of soursop (Annona muricata L.) fruits of Coast region, Tanzania

\begin{tabular}{lll}
\hline & This study & Soursop literature \\
\hline Macronutrients & $(\mathrm{mg} / 100 \mathrm{~g}-\mathrm{fw})$ & $(\mathrm{mg} / 100 \mathrm{~g}-\mathrm{fw})$ \\
Calcium & $870 \pm 29$ & $10.3[30], 14[34]$ \\
Sodium & $895 \pm 56$ & $23[25], 14[34]$ \\
Potassium & $367 \pm 49$ & $745.8[25], 270[30]$ \\
Heavy metal & & \\
Iron & $0.82 \pm 0.06$ & $0.64[32], 47[25], 0.6[34]$ \\
Zinc & $0.32 \pm 0.09$ & \\
Copper & $0.13 \pm 0.04$ & \\
Lead & $0.11 \pm 0.05$ & $<0.0015[15]$ \\
Cadmium & $<0.0015$ & \\
\hline
\end{tabular}




\subsubsection{Mineral Elements}

The levels of mineral elements are high suggesting that the soursop fruits may be useful for the strengthening of bones in the body. Calcium and sodium, at $870 \pm 29 \mathrm{mg} / 100 \mathrm{~g}$-fw and $895 \pm 56 \mathrm{mg} / 100 \mathrm{~g}$-fw respectively, were the predominant mineral elements present in the fruit. The calcium level was much higher than the values of $14 \mathrm{mg} / 100 \mathrm{~g}$ [34] and 10.3 $\mathrm{mg} / 100 \mathrm{~g}$ [30] reported for soursop fruits. Although the value of calcium in the Tanzanian soursop fruits is moderate it can still be used to contribute to the daily dietary calcium body requirement which is $2500 \mathrm{mg} /$ day [24].

The average amount of potassium in soursop fruits was $367 \pm 49 \mathrm{mg} / 100 \mathrm{~g}-\mathrm{fw}$ (Table 6). This value is high when compared to the values of $45.8 \mathrm{mg} / 100 \mathrm{~g}-\mathrm{fw}$ [25] and 270 $\mathrm{mg} / 100 \mathrm{~g}$-fw reported for soursop fruits elsewhere. The amount of potassium in the Tanzanian soursop fruits studied can be considered low since the level may not contribute significantly to the recommended daily allowance (RDA) for potassium which is $2000 \mathrm{mg}$ /day for an adult [24].

The average sodium content of $895 \mathrm{mg} / 100 \mathrm{~g}$-fw in the soursop fruits was higher than the value of $23 \mathrm{mg} / 100 \mathrm{~g}$ reported by Moos [25] for soursop fruits. The soursop fruits can contribute significantly to the daily amount of sodium needed by the body since the RDA value for sodium for adults is only $500 \mathrm{mg} /$ day [24]. Soursop fruit is therefore recommended for this.

\subsubsection{Heavy Metal Content}

The heavy metal levels observed in the soursop fruits are summarized in Table 6 . The iron content in soursop was 0.82 $\pm 0.06 \mathrm{mg} / 100 \mathrm{~g}$-fw, a value less than the value of $47 \mathrm{mg} / 100$ g-fw reported by [25] and higher than $0.64 \mathrm{mg} / 100 \mathrm{~g}-\mathrm{fw}$ reported by [13]. The value was higher than the value of 0.11 $\mathrm{mg} / 100 \mathrm{~g}-\mathrm{fw}$ reported for Botswana fruits [31]. The contribution of iron by this fruits to the normal dietary requirement is poor as the range obtained in this study is very much less than the RDA range for iron which is $8.0-20$ $\mathrm{mg} /$ day [24].

The copper content in the soursop fruits was $0.13 \pm 0.04$ $\mathrm{mg} / 100 \mathrm{~g}$-fw. This value is higher than $0.10 \mathrm{mg} / 100 \mathrm{~g}$-fw reported for Turkish pomegranate fruits [35] but less than the value of $0.32 \mathrm{mg} / 100 \mathrm{~g}$-fw reported for Indian fruits reported [33]. The level of copper obtained in this study compares very well to the level of copper reported for mangoes [5]. When these levels of copper are compared to the copper RDA level in foods of $1.2-3.2 \mathrm{mg} / 100 \mathrm{~g}-\mathrm{fw}$, these fruits can be considered as poor contributors to the $\mathrm{Cu}-\mathrm{RDA}$.

The level of zinc in soursop fruits was $0.32 \pm 0.09 \mathrm{mg} / 100$ $\mathrm{g}$-fw which was lower than the value of $0.80 \mathrm{mg} / 100 \mathrm{~g}$-fw reported for Indian pomegranate fruits [33]. However, the level of zinc in these Tanzanian soursop fruits is higher than the level in Tanzanian papaya [7] and oranges [8]. The zinc level found was well below the FAO and WHO permissible level of $6 \mathrm{mg} / 100 \mathrm{~g}$-fw [24].

Cadmium content was below the detection limit of the measurement, an observation similar to that reported for several fruits from Tanzania [5-8]. The very low amount of cadmium in this fruits shows that the fruits are not polluted and are farmed in unpolluted environments.

Lead in the soursop fruits had an average concentration of $0.11 \pm 0.05 \mathrm{mg} / 100 \mathrm{~g}-\mathrm{fw}$, a level that is much lower than the maximum permissible limit of $3 \mathrm{mg} / 100 \mathrm{~g}$-fw for lead in vegetables and thus falls within the safe limits for consumption as stated by FAO/WHO [36]. High lead levels have been reported in soils and vegetables grown close to the major roads of Dar es Salaam, Tanzania, [37] and Ethiopia [38]. This very low level of lead is generally very safe and cannot lead to any health hazard for consumers.

\section{Conclusion}

The physicochemical composition of soursop (Annona muricata L.) fruits from Coast Region, Tanzania, during ambient storage of the ripe fruits was determined. Changes in proximate composition (ash, titratable acidity, crude fat, crude fibre, moisture and sugars content), ascorbic acid level, macro-nutrients and heavy metals contents during the post harvest storage of soursop fruits were obtained. The soursop fruits had high moisture content $(>73.1 \%)$, low acidity $(<1.25 \% \mathrm{ca})$, low crude fat $(0.42 \mathrm{mg} / 100 \mathrm{~g}$-fw $)$, moderate ash content $(0.87 \mathrm{mg} / 100 \mathrm{~g}-\mathrm{fw})$ and crude fibre content $(6.09 \mathrm{mg} / 100 \mathrm{~g}-\mathrm{fw})$, high ascorbic acid content $(>19.7$ $\mathrm{mg} / 100 \mathrm{~g}$-fw), high total sugar content $(>34.3 \%)$, moderate reducing sugar content $(18.9 \%-39.2 \%)$ and sucrose content $(15.5 \%-30.0 \%)$. Of the macroelements $(\mathrm{K}, \mathrm{Ca}$ and $\mathrm{Na})$ determined, the high levels were of $\mathrm{Ca}$ and $\mathrm{Na}$ i.e. 870 and 895 mg/100 g-fw respectively. Heavy metals (Fe, Zn, Cu, Pb and $\mathrm{Cd}$ ) content was very low in the soursop fruits signifying that these fruits were free from such pollution. The compositional information of this fruit provided by this study underscores the fact that soursop fruits can be a good source and supplement of nutrients to the human body. The results emphasize that these fruits are sweeter and juicier as they are stored up to six days after harvest and should be consumed fresh within this period. Comparison of our results and $\mathrm{FAO} / \mathrm{WHO}$ standards reveals that this fruit from Coast Region, Tanzania, can play the valuable role of fulfilling daily human diet needs as well as be a healthy medical supplement for certain ailments.

More studies of similar and other properties on underutilized Tanzania fruits need to be undertaken as such studies serve as baseline information for nutrient composition of the fruits.

\section{Acknowledgement}

The authors would like to acknowledge the financial assistance from Quality Enhancement of College Teaching Education (QECTE) through Mkwawa University College of Education, Iringa, Tanzania. They also express their gratitude to the Chemistry Department, University of Dar es Salaam, for providing the laboratory facilities. 


\section{References}

[1] Luzia, D.M.M. and Jorge, N. (2012). Soursop (Annona muricata L.) and sugar apple (Annona squamosa L.): Antioxidant activity, fatty acids profile and determination of tocopherols. Nutr. Food Sci. 42(6): $434-441$.

[2] Oberlies, N.H., Chang, C.J. and McLaughlin, J.L. (1997). Structure-activity relationships of diverse Annonaceous acetogenins against multidrug resistant human mammary adenocarcinoma (MCF-7/Adr) cells. J Med Chem. 40(13): $2102-2106$

[3] Cassileth, B. (2008). Complementary therapies, herbs, and other OTC agents. Oncology (Williston Park) 22(10): 1202.

[4] Khaidatul, H.M. (2009). Physical properties of soursop (Annona Muricata L.) powder produced by spray drying. Undergraduate Project thesis, Universiti Malaysia Pahang.

[5] Othman, O.C. and Mbogo, G.P. (2009). Physico-chemical characteristics of storage-ripened mango (Mangifera indica L.) fruits varieties of eastern Tanzania. Tanz. J. Sc. 35: $57-$ 65 .

[6] Othman, O.C. (2011). Physicochemical characteristics and levels of inorganic elements in off-vine ripened pineapple (Ananas comosus L.) fruits of Dar es Salaam, Tanzania. KIST J. Sci. Technol. 1: $23-30$.

[7] Othman, O.C. (2009). Physical and chemical composition of storage-ripened papaya (Carica papaya L.) fruits of eastern Tanzania. Tanz. J. Sci. 35: $47-55$.

[8] Mbogo, G.P., Mubofu, E.B. and Othman, O.C. (2010). Post harvest changes in physicochemical properties and levels of some inorganic elements in off vine ripened orange (Citrus sinensis) fruits cv (Navel and Valencia) of Tanzania. Afr. J. Biotechnol. 9: 1809-1815.

[9] Dundar, M.S. and Saglam, H.B. (2004). Determination of cadmium and vanadium in tea varieties and their infusion in comparison with 2 infusion processes. Trace Element Electrolytes 21: 60-63.

[10] Colak, H., Soylak, M. and Turkoglu, O. (2005). Determination of trace metal content of various herbal and fruit teas produced and marketed from Turkey. Trace Elements and Electrolytes 22: 192-195.

[11] AOAC (1990). Official Methods of Analysis of AOAC International. 15th Ed. Vol. II Association of Official Analytical Chemists Washington, DC, USA.

[12] Ranganna, S. (2000). Handbook of analysis and quality control for fruit and vegetable products. $2^{\text {nd }}$ Edition. Tata MacGraw Hill Company Ltd, New Delhi.

[13] Waston, R.R., and Preedy, V.R. (2009). Bioactive foods in promoting health: Fruits and vegetables. Academic Press, UK. pp $628-629$.

[14] Onimawo, I.A. (2002). Proximate composition and selected physicochemical properties of the seed, pulp and oil of sour sop (Annona muricata). Plant Foods Hum. Nutr. 57(2): 165 171.

[15] Sacramento, C.K., Faria, J.C., Cruz, F.L., Barretto, W.S., Gaspar, J.W., and Leite, J.B.V. (2003). Physical-chemical characterization of fruit of three types of soursop trees
(Annona muricata L.). Revista Brasileira de Fruticultura. 25(2): $329-331$.

[16] Badrie, N. and Schauss, A.G. (2009). Composition, nutritional value, medicinal uses, and toxicology, In: R.R.Waston and V.R. Preedy (Ed.), Bioactive Foods in Promoting Health. Academic Press, UK. pp 621-641.

[17] Onyechi, A.U., Ibeanu, V.N., Eme, P.E. and Kelechi, M. (2006). Nutrient, phytochemical composition and sensory evaluation of soursop (Annona muricata) pulp and drink in south eastern Nigeria. IJBAS-IJENS 12: 53 - 57.

[18] Cardozo, C.J.M. and Valenzuela, J.R.C. (2012). Physico-chemical properties of the soursop fruit (Annona muricata L. cv. Elita) in postharvest. Amer. Soc. Agric. Bio. Eng. (ASABE) Paper number 121340866.

[19] Orsi, D.C., Carvalho, V.S., Nishi, A.C.F., Damiani, C. and Asquieri, E.R. (2012). Use of sugar apple, atemoya and soursop for technological development of jams: chemical and sensorial composition. Ciênc. agrotec. 36(5): 560 - 566.

[20] Bolivar, F.N.; Saucedo, V.C.; Solis P.S.; Sauri, D.E. (2009). Maduración de frutos de saramuyo (Annona squamosa L.) desarrollados en yucatán, México. Agrociencia 43: 133 141.

[21] Abbo, E.S., Olurin, T.O. and Odeyemi, G. (2006). Studies on the storage stability of soursop (Annona muricata L.) juice. Afr. J. Biotech. 5: $1808-1812$.

[22] Boakye, A.A. (2013) Assessment of some health beneficial constituents of edible portions of four underutilized fruits. M.Sc. (Food Sci. Technol.) Thesis. Univ. of Ghana.

[23] Wall, M.M. (2006). Ascorbic acid, vitamin A, and mineral composition of banana (Musa sp.) and papaya (Carica papaya) cultivars grown in Hawaii. J. Food Comp. Anal. 19: $434-445$.

[24] NRC (1989) Recommended Dietary Allowances. National Research Council. National Academy Press, Washington D.C. USA.

[25] Moos, V. (2014) Chemical composition of the Guanábana (Soursop) retrieved from http://cancer.vg/en/annona-muricata-soursop. on 10th August, 2014.

[26] Asgary, S., Sahebkar, A., Afshani, M.R., Keshvari, M., Haghjooyjavanmard, S. and Rafieian-Kopaei, M. (2014). Clinical Evaluation of Blood Pressure Lowering, Endothelial Function Improving, Hypolipidemic and Anti-Inflammatory Effects of Pomegranate Juice in Hypertensive Subjects. Phytother Res. 28: 193 - 199.

[27] Basu, A. and Panugonda, K. (2009). Pomegranate juice: a heart-healthy fruit juice. Nutr Rev. 67: $49-56$.

[28] Omoifo, C.O. (2004). Biochemical composition of Soursop fruit (Annona murata) as affected by two harvest seasons. Tropical Agricultural Research and Extension 7: 118 - 124.

[29] Ramulu, P. and Rao, P.U. (2003). Total, insoluble and soluble dietary fiber contents of Indian fruits, J. Food Composition and Analysis 16: 677 - 685 .

[30] Guyabano Nutritional value. In: Guyabano - The miracle fruit from the tropics. Retrieved from http://www.guyabano.com/Nutritional_Value.html on 14-August 2014. 
[31] Amarteifio, J.O. and Mosase, M.O. (2006). The chemical composition of selected indigenous fruits of Botswana. J. Appl. Sci. Environ. 10: 43 - 47.

[32] Morton, J.F. (1987). Soursop. In: Fruits of the warm climate. Greensboro, Media Incorporated. pp75 - 80.

[33] Priyanka, P., Sayed, H.M., Joshi, A.A., Jadhav, B.A. and Chilkawar, P.M. (2013). Studies on effect of different extraction methods on the quality of pomegranate juice and preparation of spiced pomegranate juice. Int. J. Food Sci. Nutr. Dietetics 2: $502-508$

[34] Sawant, T.P. and Dongre, R.S. (2014). Bio-chemical compositional analysis of Annona murata: A miracle fruit's review. Int. J. Univ. Pharmacy and Bio Sciences 3(2): $82-$ 104.
[35] Bayizit, A.A. (2010). Analysis of mineral content in pomegranate juice by ICP-OES. Asian J. Chem. 22: $6542-$ 6548 .

[36] Codex Alimentarius Commission, (2001). Food additives and contaminants. Joint FAO/WHO Food Standards programme. pp1-289.

[37] Luilo, G.B. and Othman, O.C. (2006). Lead pollution in urban environments of Dar es Salaam, Tanzania. Tanz. J. Sci. 32: $61-67$.

[38] Teju, E, Megersa, N., Chandravanshi, B.S. and Zewge, F. (2014). Lead accumulation in the roadside soils from heavy density motor way towns of eastern Ethiopia. Bull. Chem. Soc. Ethiop. 28(2): $161-176$. 